\title{
ECONOMIC AND STATISTICAL ANALYSIS OF THE UNEMPLOYMENT LEVEL OF UKRAINE
}

\author{
Somchenko V.V., Saienko O.R., Taran V., Popova Yu. \\ Zaporizhzhia National University \\ Ukraine, 69063, Zaporizhzhia, Zhukovsky str., 66 \\ vika-znu72@ukr.net, Saenkohelen3@gmal.com, abcdf@znu.edu.ua \\ ORCID 0000-0003-4860-0964, 0000-0001-8979-9354
}

\section{Key words:}

unemployment, growth, migration, emigration, immigration,

frictional unemployment, seasonal unemployment, structural unemployment.
The article highlights the reasons and conditions for increasing unemployment in Ukraine. The statistical indicators of unemployment growth throughout Ukraine and separately in Zaporizhzhia region are considered. Therefore, the main purpose of this study was to analyze the state of unemployment in Ukraine, to consider its causes and conditions of their occurrence and to propose methods to solve the problem. The study showed that the reasons for the increase in unemployment in the country and Zaporizhzhia region are a large number of factors, in general, the crisis in the country, military and actions in the East, the coronavirus situation, the departure of citizens abroad, increasing jobs abroad, leads to a mass exodus of citizens. It should be noted that over the last 5 years the unemployment rate has changed dramatically, but now it is increasing. It is determined that the main reasons for the increase in unemployment are: emigration, lack of jobs, unfavorable working conditions, providing better social guarantees, etc. Therefore, their study and analysis is one of the foundations for their solution. In general, if we consider the statistics of unemployment in Ukraine, we can draw several conclusions. First, our country is at the stage of rising unemployment, the causes of which are related not only to demographic, labor, social, but also political factors. Secondly, the legal framework in the field of labor is imperfect: there is a much worse state of social and labor protection, compared to European countries. This situation leads to an increase in the unemployment rate in the country every year. It should be noted that the number of jobs is decreasing, which in turn leads to the departure of citizens abroad to find better and more profitable jobs.

\section{ЕКОНОМІКО-СТАТИСТИЧНИЙ АНАЛІЗ РІВНЯ БЕЗРОБІТТЯ В УКРАЇНІ}

\author{
Сьомченко В.В., Саєнко О.Р., Таран В., Попова Ю. \\ Запорізький національний університет \\ Україна, 69002, м. Запоріжжя, вул. Жуковського, 66
}

\section{Ключові слова:}

безробіття, приріст, міграція, еміграція, імміграція, фрикційне безробіття, сезонне безробіття, структурне безробіття.
У статті висвітлено причини і умови збільшення безробіття на території України. Розглянуто статистичні показники приросту безробіття по всій Україні і окремо по Запорізькій області. Тому, основною метою даного дослідження було проаналізувати стан безробіття в Україні, розглянути його причини і умови їх виникнення і запропонувати методи вирішення поставленої проблеми. Дослідження показало, що причинами збільшення рівня безробіття у країні та Запорізькій області слугує велика кількість факторів, загалом це і кризова ситуація у країні, військові і дії на території Сходу, короновірусна ситуація, виїзд громадян країни за кордон, збільшення кількості робочих місць за кордоном, що призводить до масового виїзду громадян. Статистичні дані показують, що за останні роки збільшення безробіття припало більше на жіночу частину населення по всій Україна. Слід зазначити, що за останні 5 років показник безробіття різко змінювався, але наразі спостерігається його збільшення. Визначено, що основними причинами збільшення рівня безробіття є: еміграція, відсутність робочих місць, невигідні умови праці, надання кращих соціальних гарантій тощо. Тому, вивчення їх і аналіз є однією з основ до їх вирішення. Загалом, якщо розглядати статистичні дані безробіття в Україну, то можна зробити декілька висновків. По-перше, наша країна перебуває на стадії приросту безробіття, причини якого пов'язані не лише з демографічним, трудовим, соціальним, 
a i політичним фактором. По-друге, законодавча база у трудовій сфері недосконала: спостерігається значно гірший стан соціальної і трудової захищеності, у порівнянні з країнами Свропи. Така ситуація призводить до збільшення кожного року рівня безробіття по країні. Слід зауважити, що зменшується і кількість робочих місць, що у свою чергу призводить до виїзду громадян країни за кордон для пошуку більш кращих і прибутковіших робочих місць.

\section{Statement of the problem}

Unemployment is one of the main socio-economic problems of the country's economy, it is a threat and has become widespread. At present, there is a disturbance of supply and demand, the spread of social instability and poverty in society, irrational use of public resources, rising crime, increasing numbers of vulnerable groups and other negative socio-economic factors caused by lack of jobs in Ukraine. Unemployment is a macroeconomic problem caused by factors such as structural changes in the economy, declining economic development, scientific and technological progress, price ratios, seasonal fluctuations in production, insufficient aggregate demand, inflation, imperfect labor legislation, low level of training and retraining, insufficient employment programs and demographic processes. Unemployment is a threat to national development and security, as it can be a major cause of socio-economic destabilization among workers in large industrial and key enterprises in the country's livelihood.

Thus, the issue of unemployment is extremely relevant today, it poses a real threat to state and public welfare, which is why it requires considerable attention from the state to regulate stability, identify key factors and analyze the status of indicators that affect unemployment.

\section{Analysis of recent studies and publication}

Many works of scientists are devoted to the problems of unemployment. Such scientists as I. Davydova, D. Bohynia, G. Volynsky, V. Geets, V. Gerasymchuk, O. Grishnova, S. Dziuba, S. Doroguntsov, S. Kuznetsova, E. Libanova, G., Lukyanova, S. Mocherny, V. Onikienko, A. Chukhno, V. Halytsky, I. Motin, J. Miklosh, Y. Marshavin and others. They note that unemployment is one of the three important indicators of economic functioning and point out that in market economies, employment and unemployment are studied systematically, as information is needed to regulate the labor market, provide social protection, provide timely training and retraining. However, it should be noted that despite the large number of scientific studies, the analysis of causes, unemployment and ways to overcome unemployment as one of the global problems of the world at the present stage of reforming Ukraine's economy is relevant, needs further study and additional scientific and practical developments.

\section{Objectives of the article}

The main purpose of this study is to analyze the state of unemployment in Ukraine, to determine the reasons for its increase and the conditions of its occurrence; suggest ways to solve the problem.

\section{The main material of the research}

Unemployment in Ukraine is an urgent problem today. Its causes are an integral part of the economy. It is a complex macroeconomic factor of economic life.

According to the Law of Ukraine "On Employment", unemployment is a socio-economic phenomenon in which some people are unable to exercise their right to work and receive wages (rewards) as a source of livelihood; or it is a person aged 15 to 70 who, due to lack of work, has no earnings or other income provided by law as a source of livelihood, is ready and able to start work [1]. The status of «unemployed» is acquired by persons who are legally defined by part (Table 1) [1].

The entire population of the country can be divided into two categories: economically active population (labor force), and economically inactive population (persons outside the labor force). In turn, the economically active population consists of the unemployed and employed, ie people who have a job [4]. In Ukraine, the economically inactive population, ie persons who cannot be classified as unemployed or employed, include the following categories of citizens:

- people of working age (under 16 years);

- incapable of work (category of citizens who have never worked or stopped working due to their health condition);

Table 1 Conditions for acquiring the status of an unemployed person

\begin{tabular}{|l|l|}
\hline & \multicolumn{1}{c|}{ He can become unemployed } \\
\hline & $\begin{array}{l}\text { - a person of working age before the appointment of a pension (in particular on preferential terms or for years of } \\
\text { service), who due to lack of work has no earnings or other income provided by law, is ready and able to start work; }\end{array}$ \\
$\begin{array}{l}\text { - a person with a disability who has not reached the retirement age established by Article 26 of the Law of Ukraine } \\
\text { "On Compulsory State Pension Insurance" and receives a disability pension or social assistance in accordance } \\
\text { unemployed } \\
\text { with the laws of Ukraine "On State Social Assistance to Persons with Disabilities from Childhood and Children } \\
\text { with Disabilities" and "On state social assistance to persons who are not entitled to a pension and to persons with } \\
\text { disabilities"; }\end{array}$ \\
$\begin{array}{l}\text { - a person under the age of 16 who has worked and been dismissed due to changes in the organization of production } \\
\text { and labor, including the termination or reorganization of enterprises, institutions and organizations, the reduction } \\
\text { of the number (staff) of employees. }\end{array}$ \\
\hline
\end{tabular}


- retired pensioners on preferential terms;

- pupils, students, cadets who study in full-time educational institutions;

- persons with disabilities receiving assistance;

- category of citizens engaged in housekeeping, caring for children or sick relatives;

- citizens who could not find a job or stopped looking for it due to inability to find employment, but are ready and able to work;

- persons who do not have the need to obtain a job [6].

There are two main groups of unemployment:

- absolute unemployment - occurs in the presence of a shortage of jobs;

- relative unemployment - a type of unemployment when there is a stratification of surplus and shortage of labor across the country [7].

There are many types of unemployment, but there are two types that may include others. Namely:

- voluntary unemployment is a type of unemployment in which a person who is part of the labor force shows a desire to be temporarily unemployed, in the presence of working conditions that are not acceptable to him [7];

- forced unemployment is a type of unemployment in which a person who is part of the country's labor force does not have a permanent place of employment for reasons that do not depend on it [7].

Unemployment varies depending on the duration and socio-economic consequences, it can be frictional, seasonal, cyclical and institutional.

Frictional unemployment occurs on a voluntary basis, when a person voluntarily changes jobs or in search of a new job. Basically, this type of unemployment is desirable and inevitable, because the initiative to dismiss comes from the employee. Frictional unemployment is temporary, can last from 1 to 2 months [8].

Seasonal unemployment, as the name implies, depends on the seasonal nature of work. These usually include agricultural work, rafting, some fishing and hunting, and others. This type of unemployment is characterized by easy prognosis and the degree of voluntariness is similar to frictional [8].

Structural unemployment appears with a change in structural production and with a change in the structure of production. Scientific and technological progress, the emergence of new materials, technologies and cause structural unemployment. During it, mostly fired employees who do not meet the new requirements of the enterprise in their specialty and qualification [8].

Cyclical unemployment is the most severe form of unemployment, which is characterized by insufficient demand for labor and has the most devastating socioeconomic consequences for people [8].

The unemployment rate in Ukraine in the second quarter of 2020 increased by 1.3 percentage points. - up to $9.9 \%$ from $8.6 \%$ in the first quarter. This is evidenced by data from the State Statistics Service. In total, 1.7 million Ukrainians are unemployed. The employed population aged 15-70 in the second quarter of 2020 was 15.6 million people. The unemployment rate in Ukraine in JanuaryMarch 2020 compared to the 4th quarter of 2019 decreased by 0.1 percentage points. - up to $8.6 \%$ from $8.7 \%$ [2]. According to the government's macroeconomic forecast for the next three years, the unemployment rate for the population aged 15 to 70 is projected at $9.2 \%$ in 2021, $8.5 \%$ in 2022 and $8 \%$ in 2023 (Fig. 1).

The reasons for the increase in unemployment in the country are different. In general, among the main ones are:

- the fall of the economy and the corresponding decline in financial performance of enterprises;

- departure of citizens abroad;

- coronavirus crisis;

- lack of jobs;

- low wages;

- underdevelopment of the private sector and the existence of the shadow economy, etc.

Unemployment, as an integral part of the economy, has a negative impact on the country's GDP. After all, according to Oaken's law, an increase in the unemployment rate by more than $1 \%$ of the natural level leads to a loss of $2-3 \%$ of GDP.

If we analyze the unemployment rate in the period from 2015 to 2019, we can conclude that for 5 years in the country there has been a decrease in the unemployed population and an increase in the employed population (Table 2) [3; 5].

Thus, the level of employed population aged 15-70 years increased by 135.1 thousand. persons. The unemployment rate decreased by 166.83 thousand

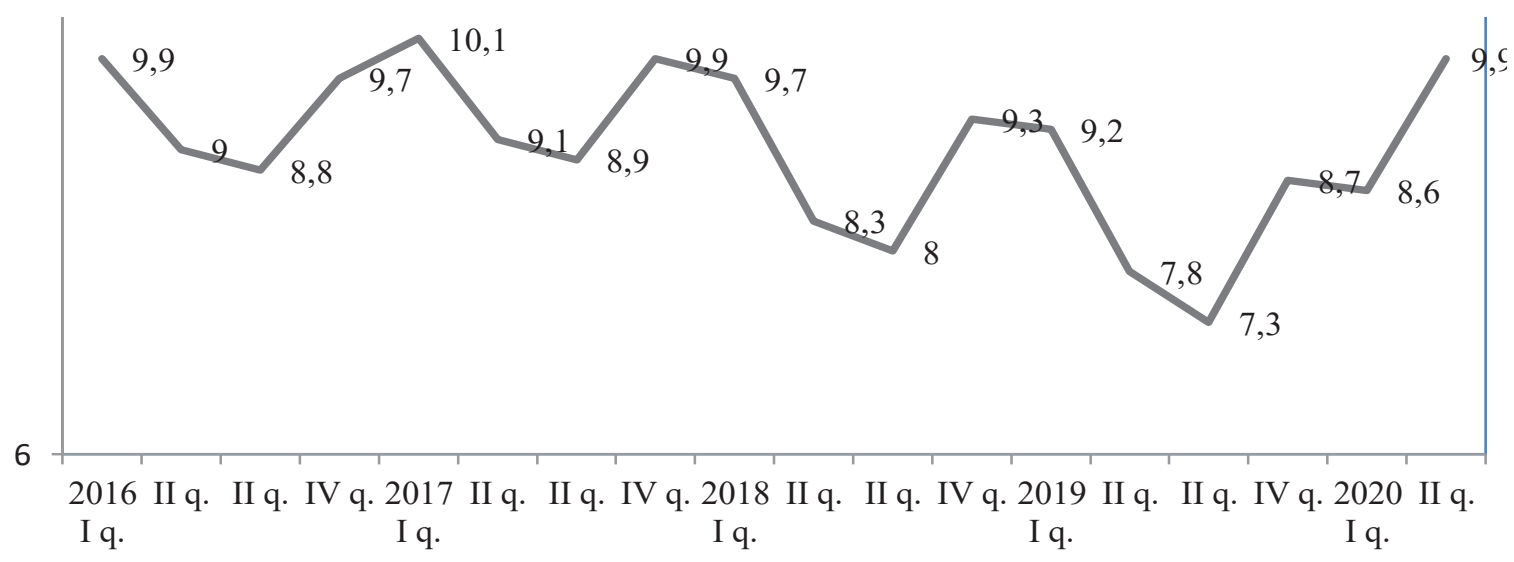

Fig. 1 Unemployment rate of the population aged 15-70 (in \% to the labor force of the corresponding age) 
Table 2 The level of employed and unemployed population in the period from 2015 to 2019

in the country and Zaporizhzhia region

\begin{tabular}{|c|c|c|c|c|c|c|c|c|c|c|c|}
\hline \multirow{2}{*}{\multicolumn{2}{|c|}{ Years }} & \multicolumn{2}{|c|}{2015} & \multicolumn{2}{|c|}{2016} & \multicolumn{2}{|c|}{2017} & \multicolumn{2}{|c|}{2018} & \multicolumn{2}{|c|}{2019} \\
\hline & & \multirow{2}{*}{\begin{tabular}{|l|} 
Ukraine \\
16443,2 \\
\end{tabular}} & \multirow{2}{*}{\begin{tabular}{|c|}
$\begin{array}{c}\text { Zapori- } \\
\text { zhzhia }\end{array}$ \\
745,1 \\
\end{tabular}} & \multirow{2}{*}{$\begin{array}{c}\text { Ukraine } \\
1627,69\end{array}$} & \multirow{2}{*}{\begin{tabular}{|c|}
$\begin{array}{c}\text { Zapori- } \\
\text { zhzhia }\end{array}$ \\
734,9 \\
\end{tabular}} & \multirow{2}{*}{$\begin{array}{c}\text { Ukraine } \\
15495,9\end{array}$} & \multirow{2}{*}{\begin{tabular}{|c|}
$\begin{array}{c}\text { Zapori- } \\
\text { zhzhia }\end{array}$ \\
694,3 \\
\end{tabular}} & \multirow{2}{*}{$\begin{array}{r}\text { Ukraine } \\
16360,9\end{array}$} & \multirow{2}{*}{\begin{tabular}{|c|}
$\begin{array}{c}\text { Zapori- } \\
\text { zhzhia }\end{array}$ \\
732,2 \\
\end{tabular}} & \multirow{2}{*}{$\begin{array}{l}\text { Ukraine } \\
165783,3\end{array}$} & \multirow{2}{*}{$\begin{array}{c}\begin{array}{c}\text { Zapori- } \\
\text { zhzhia }\end{array} \\
741,6\end{array}$} \\
\hline At the age of & $\begin{array}{l}\text { Employed } \\
\text { population }\end{array}$ & & & & & & & & & & \\
\hline $15-70$ years & $\begin{array}{c}\text { Unemployed } \\
\text { population }\end{array}$ & 1654,7 & 80,4 & 1678,2 & 81,4 & 1698,0 & 86,2 & 1578,6 & 80,4 & 1487,87 & 77,5 \\
\hline \multirow{2}{*}{ Working age } & $\begin{array}{l}\text { Employed } \\
\text { population }\end{array}$ & 15742,0 & 709,5 & 15626,1 & 708,0 & 16156,4 & 719,7 & 15718,6 & 702,7 & 15894,9 & 707,7 \\
\hline & $\begin{array}{c}\text { Unemployed } \\
\text { population }\end{array}$ & 1654,0 & 80,4 & 1677,5 & 81,4 & 1697,3 & 86,2 & 1577,6 & 80,4 & 1486,9 & 77,5 \\
\hline
\end{tabular}

* Source: compiled by the author

people. In Zaporozhzhye, this figure was respectively 3.5 thousand people and 2.9 thousand people.

If we consider the employment rate of people of working age, the employment rate increased by 152.9 thousand people, and unemployment decreased by 2.9 thousand people. In Zaporizhzhia, this figure was 1.8 thousand people and 2.9 thousand people, respectively.

If we consider the unemployment rate, using the distinction by sex in the period from 2017 to 2019, we obtain the following data (see Fig. 2).

The unemployment rate among women has increased significantly, from 2017 to 2019, this figure increased by 155.3 thousand people. Such changes can be due to a number of reasons: demographic factor, economic crisis, political changes, etc.

Among men, the number of unemployed decreased by much -365.6 thousand people. Such positive changes have several reasons, in general: the demographic factor, hostilities in the Donbass (a significant number of men received working months at the forefront), increasing the number of jobs abroad, and others.

Migration is also one of the key reasons for rising unemployment. It can be divided into external and internal.

Internal, this is a migration that occurs between separate administrative units of one state, at different levels.

External, in turn, occurs between states, regions of the planet, continents. They include:

- emigration (departure of citizens of a particular state abroad);
- immigration (entry of foreign citizens into a particular country);

- re-emigration (return of former or current citizens of the state to their homeland);

- repatriation (return of people who were forcibly deported).

If we consider the duration, they are divided into:

- permanent (moving to permanent residence);

- temporary (moving for a relatively short period);

- seasonal (connected with seasonal work, resort rest, etc.);

- pendulum (regular daily or weekly trips to work or study).

If we consider the situation based on statistics, we obtain the following data shown in table 3 .

Among EU countries, the largest number of migrations is observed in Poland. This is due to the fact that our citizens provide jobs with higher pay than in Ukraine. Also a high rate of labor migration to the Russian Federation. The reasons include the provision of jobs and the lack of a language barrier. A significant figure is also observed in Italy, where the percentage of women's labor migration is much higher. This is due to the high number of jobs for women.

Thus, analyzing the data, we can conclude that in the period from 2015 to 2018 in Ukraine there is a significant increase in the number of emigrants. This is primarily due to more favorable working conditions and wages, providing our citizens with a wider range of jobs. Also, a significant

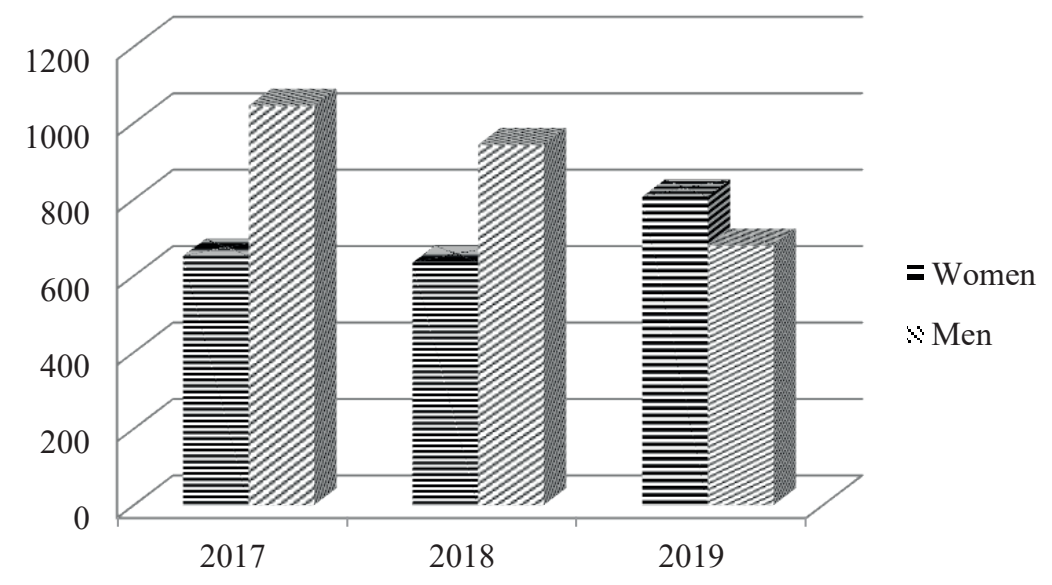

Fig. 2 The level of the unemployed population in 2017-2019 by sex 
Table 3 Migrant workers by country of residence, sex and place of residence before leaving for abroad, 2015-2017

\begin{tabular}{|c|c|c|c|c|c|}
\hline & Total & Women & Men & Urban settlements & Countryside \\
\hline The number of migrant workers, in total, thousand people & 1303,3 & 385,8 & 917,5 & 663,5 & 639,8 \\
\hline \multicolumn{6}{|l|}{ including by host country, $\%$} \\
\hline Poland & 38,9 & 42,6 & 37,3 & 38,3 & 39,5 \\
\hline Russian Federation & 26,3 & 15,1 & 31,0 & 33,0 & 19,3 \\
\hline Italy & 11,3 & 27,0 & 4,7 & 7,3 & 15,4 \\
\hline Czech Republic & 9,4 & 6,2 & 10,7 & 5,2 & 13,7 \\
\hline United States & 1,8 & - & 2,6 & 3,5 & - \\
\hline Belarus & 1,7 & 0,8 & 2,1 & 0,9 & 2,6 \\
\hline Portugal & 1,6 & 0,4 & 2,0 & 2,1 & 1,0 \\
\hline Hungary & 1,3 & 0,9 & 1,5 & 1,2 & 1,5 \\
\hline Israel & 1,1 & 0,6 & 1,3 & 1,9 & 0,2 \\
\hline Finland & 1,0 & 0,8 & 1,1 & 0,8 & 1,3 \\
\hline Germany & 0,8 & 0,5 & 0,9 & 1,1 & 0,4 \\
\hline Other countries & 4,8 & 5,1 & 4,8 & 4,7 & 5,1 \\
\hline
\end{tabular}

Source: Derzhkomstat [9]

factor in the departure of citizens to work abroad is the provision of social benefits and guarantees.

\section{Conclusions}

Among the main factors of the country's well-being is the unemployment rate. The analysis of this indicator in Ukraine showed that there are large enough problems that need to be addressed. In general, the problem of unemployment in Ukraine has existed for a long time, but it began to develop especially acutely in the last 5 years. According to a study of statistics - the unemployment rate has decreased, but in reality, this figure is only increasing. After all, the comparison is made in relation to the entire existing population, which is only decreasing in Ukraine. Also, one of the reasons for the change could be the increase in the number of people working abroad.

Unemployment itself can be seen as an imbalance in labor supply and demand, and its causes can be related to economic, political, demographic, social and many other reasons.

Therefore, in order to prevent a critical situation, first of all it is necessary to pay attention to the legal, economic, organizational and social nature and to develop a system of human resources, which will be the goal of further research.

Also, it is necessary to take into account the legal framework, namely the laws governing the rights of workers and employers. Pension reform should not be overlooked either, as there is currently a known dissonance between the number of employees and the number of retirees. In order to better regulate employment, it is necessary to resolve the contradictions of legal, economic, organizational and social nature and to develop a system of staffing, which will be the goal of further research.

To encourage workers, the main goal of the state should be to increase jobs with favorable wages and comfortable working conditions. Thus, it may be of interest to more workers to stay in the country rather than go abroad.

Therefore, solving the problem of high unemployment should be considered at all levels. Given the current state of Ukraine's economy, the best solution to this problem is: the use of active political employment, among the main - increasing the number of self-employed; reducing the difference in terms of reproduction of labor potential between regions; maximum approximation of demand to labor supply; increasing labor mobility, etc.

\section{References}

1. Pro zaynyatist' naselennya : Zakon Ukrayiny vid 04.03.2021., pidstava 1212-9. Available at: http://zakon0.rada.gov.ua/ laws/show/5067-17

2. Ekspres-vypusk Derzhavnoyi sluzhby statystyky Ukrayiny «Zaynyatist' ta bezrobittya naselennya v II kvartali 2020 roku». Available at: http://www.ukrstat.gov.ua/express/expr2020/09/118.pdf

3. Derzhavnyy komitet statystyky (2020) «Bezrobitne naselennya (za metodolohiyeyu MOP) za rehionamy Ukrayiny». Available at: http://www.ukrstat.gov.ua/operativ/operativ2009/rp/rp_reg/reg_u/arh_bn_u.htm

4. Derzhavnyy komitet statystyky «Metodolohichni polozhennya shchodo klasyfikatsiyi ta analizu ekonomichnoyi aktyvnosti naselennya». Available at: http://www.ukrstat.gov.ua/metod_polog/metod_doc/2011/12/metod.htm

5. Derzhavnyy komitet statystyky (2020) «Zaynyatist' naselennya za stattyu, typom mistsevosti ta vikovymy hrupamy». Available at: http://www.ukrstat.gov.ua/operativ/operativ2017/rp/eans/eans_u/arch_znsmv_u.htm

6. Yesinova, N.I. (2017) Ekonomika pratsi ta sotsial'no-trudovi vidnosyny : navch.-metod. posib. Kharkiv : KHDUKHT.

7. Vorobyova, Ye.M. (2019) Ekonomichna teoriya : navch. posib. Kharkiv : KHNU imeni V.N. Karazina.

8. Pavlyuk, T.I., Nechytaylo, T.Yu. (2019) Bezrobittya: prychyny ta shlyakhy yoho podolannya. Available at: http://molodyvcheny.in.ua/files/journal/2019/11/122.pdf

9. The main site of the State Statistics Service of Ukraine (2018), «Zovnishnya trudova mihratsiya naselennya Ukrayiny za 2015-2017 roky». Available at: http://www.ukrstat.gov.ua/druk/publicat/kat_u/publ11_u.htm 